\title{
ELIMINATING ARCHAIC FEATURES OF EXECUTION PROCESS IN PENNSYLVANIA.
}

For a commercial community it is of great importance that the legal machinery for collecting debts should be both just and swift. The increased recognition of this fact in the past few years has had its effect in Pennsylvania as elsewhere. In IgII, the General Assembly established a municipal court in Allegheny County, and in 1913 a similar court in. Philadelphia, in order to relieve the congestion of business in those counties. The new rules of court promulgated by the Courts of Common Pleas of Philadelphia County in 1913 show the effect of this general feeling. Perhaps the most marked change is the great reduction in the length of time required to reach trial in Philadelphia County. Commercial cases may now be tried in the Common Pleas within six months from the time of ordering on the trial list; in the Municipal Court, the time is from two to three weeks.

But all this expedition in arriving at a judgment is of little worth unless proper means are supplied for enforcing the payment of the judgment. The Legislature provided unsatisfied judgment creditors with a much needed weapon by the Act of May 9, 1913, which provided for the oral examination of judgment debtors before the court. But there still exist anachronisms which hinder or delay the creditor to whom money. is justly due. It is the province of this article to point out three of these undesirable features of our statute law.

\section{Inguisition Upon Real Estate.}

In the ordinary commercial case where the plaintiff has obtained a judgment, he must, to enforce payment, sue out a writ of fieri facias directing the sheriff that "of the goods and chattels, lands and tenements of John Smith, defendant," he "cause

'P. I. 197.

(652) 
to be levied" the amount of the judgment with interest and costs. If the defendant has personal property the sheriff not only levies on it in obedience to the writ, but proceeds to sell it, in order to pay the plaintiff's judgment. If, however, it becomes necessary to resort to the defendant's real estate, the sheriff levies on the real estate and then, instead of selling it, proceeds to "șummon an inquest of six men, for the purpose of ascertaining whether the rents and profits of such estate, beyond all reprises, will be sufficient to satisfy within seven years the judgment on which such execution was issued with the interest and costs of suit."2 The purpose of this "inquisition" is, of course, to give the defendant a chance to save his land. If there is no condemnation, i. e., if the inquest find that the rents, etc., will pay the judgment in seven years, the defendant may, with the plaintiff's permission, continue to occupy the land so long as he makes certain half-yearly payments on account of the debt. Or the plaintiff may, at his option, have a writ of liberari facias by virtue of which he obtains possession of the land and holds it till he has taken the amount of his judgment out of the rents and profits.

The history of this practice is interesting. In England, before 1285 , a judgment creditor might have a writ of fieri facias directing the sheriff to sell the goods of the debtor, or he might have a writ of levari facias, directing the sheriff to seize the debtor's goods and receive the rents and profits of his lands, till the debt was satisfied; but he had no means of subjecting the land itself to the payment of the debt, for such a remedy would have undermined the feudal rights of the debtor's lord. In I285 was enacted the Statute of Westminster II, 3 creating a new writ thereafter called an elegit, to which a judgment creditor was to be entitled at his election. The writ of elegit directed the sheriff to deliver to the creditor "all the chattels of the debtor (saving only his oxen and beasts of his plough) and the one-half of his land,

'Act of May 10, 1881, 81, P. L. 13, (Purdon's Digest, 1563).

13 Edw. I. c 18 
until the debt be levied upon a reasonable price or extent." In accordance with this statute the defendant's goods and chattels were not sold but were delivered to the plaintiff at an appraised value. If this value was not sufficient to satisfy the debt the sheriff delivered to the plaintiff one-half of the defendant's freehold lands to hold until the amount of the debt should be levied out of the rents and profits. ${ }^{4}$ This is the system in force in England today, save that by statute ${ }^{5}$ the sheriff is empowered to deliver to the creditor all, instead of half of the debtor's lands.

In Pennsylvania, the first Assembly held at Upland (Chester) ratified "the laws agreed upon in England," which made all lands and goods liable to pay debts, "except where there is legal issue, and then all the goods and one-third of the land only." Three days later, on December 7, 1682, in The Great Law, the Assembly proceeded to change the law which related to execution against lands by making one-half of the debtor's land, instead of one-third, liable to execution where there was legal issue. ${ }^{7}$ By a law passed May Io, I688, appraisement by "twelve honest and discreet men of. the neighborhood" was provided for, ${ }^{8}$ apparently in case the land was to be handed over to the creditor in whole or part payment of the debt. This enactment survived with some vicissitudes until iz05. All of these seventeenth century statutes show the effect of feudal ideas by restricting the amount of land liable to pay debts in cases where there was legal issue.

In 1705 was passed the act ${ }^{9}$ from which our present practice has arisen. That act provided for an inquest of twelve who should decide whether the net profits of the land would pay the debt in seven years. If they would, the sheriff was to deliver the land to the plaintiff as on writs of clegit in England; if they

\footnotetext{
- See Blackstone's Commentaries, Book 3, p. 418.

I and 2 Vict. c. 110 (1838).

- Duke of York's Laws, p. 100

'Duke of York's Laws, p. 120.

-Duke of York's l.aws, p. 180

-I Dall. 67.
} 
would not, the creditor was to be entitled to a writ of venditioni exponas. This act and others amendatory of it, were substantially re-enacted on June $16,1836 .{ }^{10}$ Since that date the law has been changed in some particulars, but the backbone of it is still the Act of 1705 .

When personal property is taken in execution, the defendant has no right under any circumstances to oblige the plaintiff to accept payment by installments spread over a number of years. If the judgment is not paid, the court, at the creditor's request, directs the sheriff to sell the debtor's goods and to pay the creditor's claim out of the proceeds, and there is an end of the matter. That the situation should be different where real estate is involved is due to the peculiar and almost superstitious regard of our ancestors for that species of property, and to their strong feudal feeling that land should remain in one family as long as possible. But why today distinguish a store-keeper's stock-in-trade from the store in which he conducts his business? His bread and butter come alike from both. If the peculiar protection given by law to all real estate were limited to a debtor's dwelling-house, the principle would be more reasonable. But to establish an arbitrary distinction between all personal property and all real property is no longer either necessary or convenient, since it merely serves to confer a chance benefit upon the fortunate owner of land, and to impose a burden upon the creditor of such an owner.

The application of this practice when life estates are levied upon, is peculiarly valueless. A debtor's life estate is ordinarily levied upon, condemned and sold just as in the case of estates of inheritance, except in the rare instances in which a liencreditor asks for the appointment of a sequestrator. It is diffcult to understand how the inquest can decide what an estate will produce in seven years, when it may terminate in twenty-four hours. And yet the present practice extends to life estates. ${ }^{11}$ The

"P. L. 761, (Purdon's Digest, i5I5 et seq.).'

"Act of January 24, 1849, $\$ \$ 3$ \& 4, P. L. 677, (Purdon's Digest, 1574); Commonweaith v. Allen, 30 Pa. 49 (1858); Moyer v. Casper, $7 \mathrm{~Pa}$ Dist. Rep. 720 (1898). 
Commissioners on the Civil Code in reporting the Act of 1836 stated that they considered the then practice of selling life estates on a ficri facias to be unfair to the debtor because it resulted in selling at a sacrifice. They accordingly proposed the system of sequestration which was adopted by the Legislature. In thirteen years it was realized that life estates ought to be subject to sale just as any other estate and Sections Three and Four of the Act of January $24,1849,{ }^{12}$ were passed accordingly.

A further and perhaps even stronger argument in favor of changing the present system is to be found in the history of its practical application. In Philadelphia County one inquest is summoned in respect of all the real estate taken in execution in a given month. The inquisition is purely perfunctory unless the defendant wishes to produce testimony. The sheriff and the six members of the inquest sign their names to a printed form which is returned with the writ, stating that the "rents, issues and profits" of the property in question "are not of a clear yearly value beyond all reprises, sufficient within the space of seven years to satisfy the debt and damages in the writ aforesaid mentioned." One would suppose, if he were not familiar with our system, that the sheriff could sell the property as soon as the inquest had performed this duty. But instead of this, he is bound to make a return to the court, showing the condemnation, and the plaintiff must then sue out a writ of venditioni exponas directing the sheriff to sell. Where the inquest by their finding have shut off the defendant's hope of further delaying the plaintiff, why must the plaintiff resort to another writ in order to have his remedy? Why is not one writ sufficient to cover the whole situation?

That there should be but one writ directing the sheriff to advertise and sell forthwith and dispensing with the formality of an inquest, becomes apparent when we consider how regularly condemnation is the result of inquisition. In Philadelphia County an inquest has failed to condemn only once in the past

P. L. 677, (Purdon's Digest, 1574). 
ten years. In Luzerne, Northumberland, Montgomery, Lehigh, Delaware and Franklin Counties there has been no failure to condemn for ten years past. In Berks, there have been two failures in eighteen years. In Allegheny County, the inquest fail to condemn only three or four times a year. No writ of liberari facias has been issued in any of these counties for many years, so far as the writer can ascertain. On the rare occasions when the inquest has failed to condemn, the plaintiff has allowed the. defendant to retain possession of the land, and to pay the judgment in half yearly installments. It does not seem wise or fair that hundreds of judgment creditors should every year be put to extra expense and delay in order to afford to a very few debtors a relief to which they are really not entitled.

To abolish the inquest and permit immediate sale upon the fieri facias (as is now the practice where inquisition has been waived) would save four dollars and twenty-five cents in cash and much time. Writs of fieri facias to sell real estate are now returnable in Philadelphia County on the third Monday of September, and on the first Monday of each other month. A plaintiff, let us suppose, sued out a fieri facias on January 24 , 1914, the writ was returnable Monday, February 2, and a venditioni exponus issued as late as February 5 was in time for the sale on March 2. The plaintiff would have been saved money, but not time, by the abolishment of the inquest and venditioni exponas, since he was too late for the February sale and must have waited till the March sale in any event, in order to give time for the required advertising. But suppose the same plaintiff had been unable to sue out his fieri facias until January 26 (January 25 was Sunday), it would then have been too late to have the writ returnable Monday, February 2, because the statute requires five days' notice of the inquisition to be given to the defendant. The ficri facias would, therefore, have been returnable Monday, March 2, and a sale could not have been had till April 6. Had there been no inquisition and no necessity of issuing a venditioni exponas the land would have been sold on March 2. 
The table contained in the note will show the saving of time which the suggested change in procedure would bring about in Philadelphia County. ${ }^{13}$

An examination of the statutes of the forty-eight states shows that the Pennsylvania system is unique and that it is surpassed in efficiency by the systemis of most of our sister states. In thirty-two states, including our neighbors, New York, New Jersey and Maryland, land is sold upon the original writ after proper advertisement. This method is simple, expeditious and sensible. In eleven states the sale is preceded by an appraisement, either to enable the plaintiff to take the land at its appraised value ${ }^{14}$ or to establish a value two-thirds of which at least must be bid in order to effect a sale. ${ }^{15}$ In Connecticut real estate is not sold in execution but is "set out" to the judgment creditor at an appraised value in whole or partial satisfaction of his debt. In Virginia and West Virginia, the land may be taken

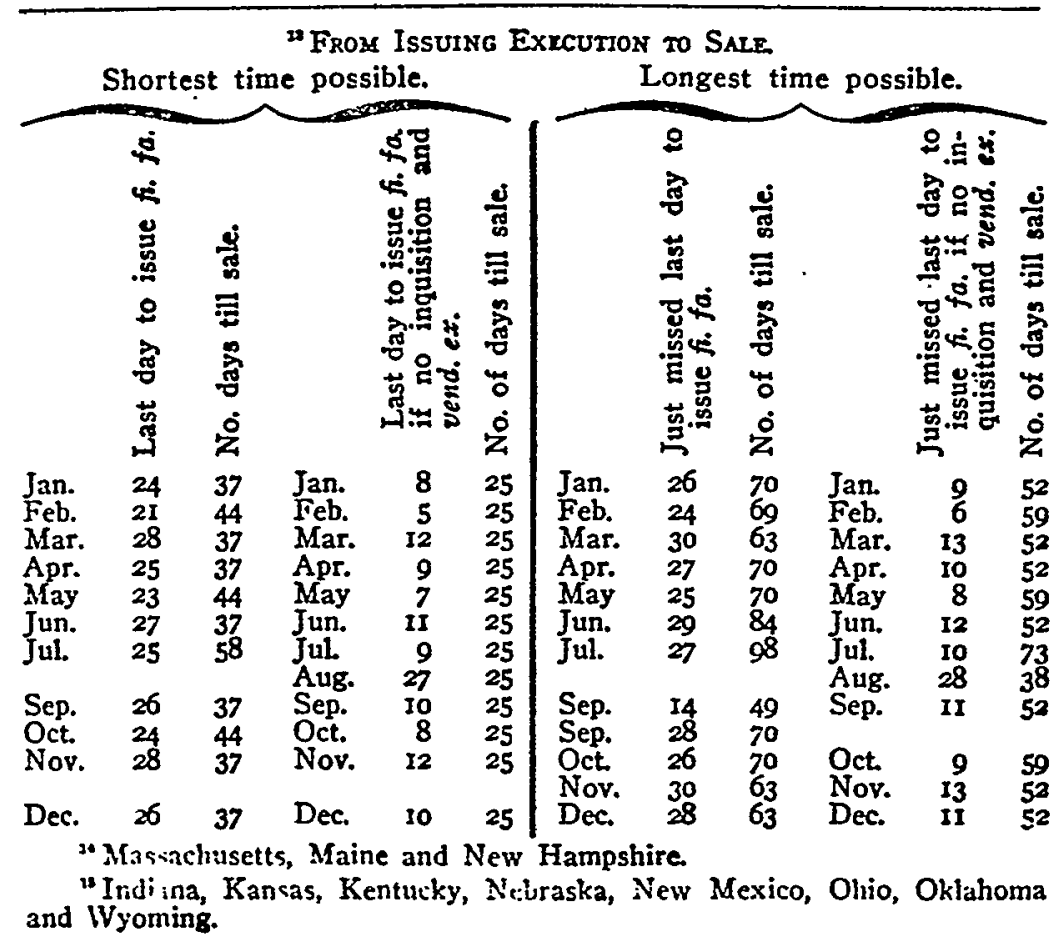


in execution only by resorting to Chancery. The court will decree a sale if it appears that the rents and profits of the land will not pay the judgment in five years, otherwise the court will decree a renting of the property till the judgment is paid. Whatever may be the defects of these systems they at least do not require under all circumstances two writs for the sale of real estate. The system in Delaware more nearly resembles our own than does that of any other state. In that state there is an inquisition by two freeholders, but only if the plaintiff demands it. If an inquisition were held in Pennsylvania only on demand of the plaintiff, the sheriff would seldom be called upon to summon an inquest.

It is time that our unique. and cumbersome system be discarded, so that a judgment creditor whose judgment remains unsatisfied, may forthwith procure his debtor's land to be sold without the loss of valuable time and money.

\section{Judgment Against the Mortgagor in a Scire Facias Sur Mortgage.}

When the oiwner of mortgaged land defaults in the payment of interest or principal, the mortgagee's common remedy is by a writ of scire facias. By the Act of January 12, 1705, ${ }^{16}$ it is provided that the writ of scire facias shall require the sheriff "to make known to the mortgagor or mortgagors, his, her or their heirs, executors or administrators, that he or they be and appear before the magistrates, judges, or justices of the said court or courts, to show if anything he or they have to say, wherefore the said mortgaged premises ought not to be seized and taken in execution." Under this act it was decided that the owner of the property need not be made a party defendant in the scire facias, ${ }^{17}$ and that two returns of nihil habet as to the mortgagor were equivalent to a return of scire feci, ${ }^{18}$ so that mortgaged land could be sold at sheriff's sale without actual notice of the sale either to the mortgagor or to the owner. Under such circumstances, however, the owner was not precluded by the judgment

\footnotetext{
: I Sm. 59, \$6, (Purion's Dijest, 1194).

"Mither v. Clark, I Watts. 49I (18.33).

" Varder v. Tainier. 4 l'atts, 270 ( I835).
} 
from making any defense against the purchaser which he might have had against the mortgagee, ${ }^{19}$ so that it was good practice to make the owner a party defendant in the scire facias.

The Act of July 9, 1901, ${ }^{20}$ and the Act of April 23, 1903, ${ }^{21}$ which amended it, recognized the fact that the owner of the property was the actual defendant in foreclosure proceedings and accordingly directed that he be made a party defendant in the scire facias and served by the sheriff. But the mortgagor or his heirs, executors or administrators must still be served in the oldfashioned way, i. e., either actually or by two returns of nihil habet. Then, if neither mortgagor nor real owner have anything to say wherefore the said mortgaged premises ought not to be seized, and usually they have nothing to say, the plaintiff takes judgment against each of them and sues out a writ of levari facias directing the sheriff to sell the land.

Unless the mortgagor be also the real owner, a judgment against him is obviously of no use as far as the mortgaged land is concerned. The value of obtaining a judgment against the mortgagor lies in the fact that it fixes the amount of damages as against him, so that he will be precluded by the amount so fixed upon a subsequent suit upon his bond. Thus, if the sale under the foreclosure nets the plaintiff one thousand five hundred dollars, out of a real debt of two thousand dollars, the damages in the judgment upon the bond will be assessed at five hundred dollars.

It will be observed that the mortgagor, with no notice of the proceedings whatever, may be precluded with respect to the amount of damages by a judgment obtained upon two returns of silhil habet: Probably such a judgment or a subsequent judgment upon the mortgagor's bond could be opened if the mortgagor had a defense, ${ }^{22}$ so that they are not equivalent to judgments obtained after actual service of process. But whether or not judg-

\footnotetext{
"Mather v. Clark, supra.

* P. L. 6r4, 81, C. 10.

21. L. 261, \$I, (Purdon's Digest, 240).

"See Warder v. Tainter, 4 Watts; 270 (1835); Green v. Plattsburg et al., 13 P2. C. C. 335 (1893).
} 
ment in such a case can be opened upon showing that there is a good defense and that there was no actual service of process, why require the plaintiff to go through the formality of obtaining two returns of nihil habet? Why not allow him to enter judgment against the mortgagor as an incident to entering judgment against the real owner? The same effect is reached without the use of purely formal and unavailing proceedings. Or better still, why not dispense entirely with judgment against the mortgagor in the foreclosure proceedings, and allow a judgment on the bond to be opened if the mortgagor has a good defense?

The suggested change would assure to the mortgagor his proper rights and would in every case save labor for prothonotary, sheriff and attorney. It would often save the cost of issuing an alias scire facias, seventy-five cents, and would always save the cost of getting returns as to the mortgagor, which, when there are two returns of nihil habet, is two dollars, and when the mortgagor is actually served, may be more. Lastly it would often save time.

Writs of scire facias are returnable in Philadelphia County, which may be taken as a convenient example, on the first and third Mondays of every month. Suppose that a scire facios sur inortgage was issued on Saturday, February 14, 1914, returnable on Monday, February I6 (the third Monday in February), naming as defendants John Doe, mortgagor, deceased, and Geoffrey Stiles, real owner. The sheriff served Stiles and handed a copy of the writ to the person in actual possession of the land. Finding no trace of Doe or of any of his heirs, executors or administrators, he returned nihil labet as to him (or perhaps the plaintiff sirnply directed him to make such a return.) The plaintiff sued out an alias scire facias, returnable Monday, March 2, and this the sheriff also returned nikil habet as to John Doe, mortgagor. On Saturday, March 7 , the plaintiff was entitled to judgment against Stiles for want of an affidavit of defense since that was the third Saturday after the return day of the original writ; but jurlgment could not be taken against Doe for want of an appearance until fourteen days after the return day of the alias scire facias, i. e.,. March 17. A lezrari façias issued on 
March I 7 missed the April sheriff's. sale and resulted in a sale of the real estate on May 4.

Had it not been necessary in the above case to obtain two returns of sihil habet as to the mortgagor, the property would have been sold in April instead of in May, as will be seen by the following comparison:

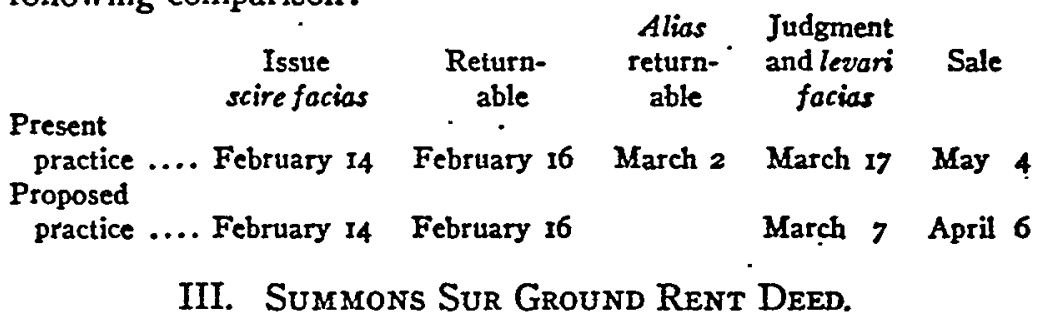

The same general considerations apply to the suing out of ground rents, and with additional force because of the considerable cost of advertising the alias writ. When the owner of premises charged with a ground rent defaults in payment, the owner of the ground rent usually enforces his rights by an action of assumpsit. When it is remembered that the amount involved is often less than two hundred dollars, the complicated procedure seems a little too much for the occasion. In this proceeding, as in the foreclosure of a mortgage, the plaintiff must obtain judgment not only against the owner of the land, but against the original covenantor, who has usually been dead for years past.

Take for example an imaginary case in Philadelphia County. On Saturday, January I7, I9I4, a summons sur ground rent deed was issued, naming as defendants Robert Smith, original covenantor, deceased, and William Jones, real owner. The sheriff served Jones, handed a copy of the writ to the person in actual possession of the land and returned nihil habet as to Smith. The plaintiff was fortunate enough to get these returns made by Tuesday, Jantiary 20, and thereupon sued out an alias summons returnable Monday, February 2. This alias summons was served by the sheriff upon the person in possession of the premises and advertised in the "Legal Intelligencer" and in one daily paper once a week for two successive weeks at a cost of twelve dollars. The plaintiff could not take judgment against the original cove- 
nantor for want of an appearance until fourteen days after the return day of the alias writ, that is, February 17 . He sued out a ficri facias returnable on the first Monday of March and after condemnation by the inquest, sued out a venditioni exponas which finally procured the sale of the property on April 6. The plaintiff spent in this process seventy-nine days and about twenty-five dol-. lars to recover a debt of probably less than two hundred dollars. Had the deputy sheriff taken a little longer to serve the first writ and made his return on January $2 \mathrm{r}$, instead of January 20 , the plaintiff would have lost another month's time; for in that case his alias summons would have been returnable February I7, judgment could have been entered March 4, the fieri facias would have been returnable April 6 and the venditioni exponas would have been returnable on May 4.

A judgment against the original covenantor is seldom of any use whatever to the plaintiff, since the Supreme Court has decided in Quain's Appeal, ${ }^{23}$ and again in Williams's Appeal, ${ }^{24}$ that the personal representatives of a deceased covenantor are liable only for ground rent accrued up to the date of the covenantor's death. The only cases in which such a judgment can be valuable to the plaintiff are cases in which all or part of the ground rent in arrears has accrued during the covenantor's lifetime, and such cases are today rare.

In the ordinary case, since the Act of June $12,1878,{ }^{25}$ and the decisions cited above, a ground rent suit is really a proceeding in rem and not in personam, though it is technically conducted as a proceeding in jersonam.

It is to be hoped that the Legislature will pass an act which will permit a plaintiff in an action of assumpsit sur ground rent deed to sell the premises after obtaining a judgment against the owner alone. He should have the privilege of joining the covenantor as a defendant or of not joining him, as he may desire. In the great majority of cases he would elect not to join the covenantor, and would therefore save time and the costs of issu-

\footnotetext{
$22 \mathrm{~Pa} 510$ (1854).

${ }_{47} \mathrm{~Pa} .283$ (1864).

* P. L 205, (Purdon's Digest, 4044).
} 
ing, serving and advertising the alias writ. Such a statute, coupled with the abolition of the inquest as suggested above would greatly simplify and expedite the present expensive, complicated and tedious system of collecting ground rents by suit.

Philadelphia, November 6, 1914 .

Shippen Lewis. 